\title{
KETERKAITAN PENCAPAIAN NILAI AKHIR DENGAN PEMAHAMAN KONSEP MATEMATIS MAHASISWA CALON GURU
}

\author{
Ayu Faradillah \\ ${ }^{1}$ Universitas Muhammadiyah Prof. DR. HAMKA, Jl.Tanah Merdeka, Jakarta Timur \\ ayufaradillah@uhamka.ac.id
}

\begin{abstract}
Abstrak
Penelitian ini bertujuan untuk menganalisis keterkaitan pencapaian nilai akhir dengan pemahaman konsep pada mata kuliah program linier. Subjek penelitian ini adalah mahasiswa semester 5 Program Studi Pendidikan Matematika Universitas Muhammadiyah Prof. DR. HAMKA (UHAMKA). Metode penelitian ini dikategorikan sebagai penelitian eksploratif dengan pendekatan kualitatif dimana peneliti mencoba menganalisis dan mendeskripsikan paparan keterkaitan pencapaian nilai akhir dan pemahaman konsep matematis pada mata kuliah program linier. Adapun indikatorindikator pemahaman konsep matematis pada penelitian ini adalah menyajikan konsep dalam berbagai bentuk representasi matematis, menggunakan prosedur atau operasi tertentu, mengaplikasikan konsep atau algoritma pemecahan masalah.
\end{abstract}

Kata Kunci: keterkaitan, pencapaian nilai akhir, pemahaman konsep matematis

\begin{abstract}
This study aims to analyze the relevance of the achievement of the final result with the understanding of the concept in the linear program lecture. The subject of this research is 5th semester students of Mathematics Education Study Program of University of Muhammadiyah Prof. DR. HAMKA (UHAMKA). This research method is categorized as explorative research with qualitative approach where researcher tries to analyze and describe exposure of attainment of final value achievement and understanding of mathematical concept in linier program. The indicators of understanding of mathematical concepts in this study is to present the concept in various forms of mathematical representation, using a particular procedure or operation, applying the concept or problem-solving algorithm.
\end{abstract}

Keywords: relevance, achievement of final result, understanding of mathematical concepts

\section{Pendahuluan}

Penilaian pada proses belajar mengajar merupakan proses memberikan atau menentukan nilai atau hasil akhir kepada mahasiswa berdasarkan kriteria tertentu. Dalam menentukan seberapa maksimal suatu proses belajar mengajar, seorang dosen haruslah mengevaluasi hal-hal yang menjadi bagian dari proses belajar mengajar. Sehingga ia dapat menjadikan bahan evaluasi tersebut sebagai cermin untuk melihat apa-apa saja yang kurang dan harus diperbaiki. Pada kenyataannya, mahasiswa hanya melihat dari nilai akhir atau hasil akhir yang diperolehnya pada proses pembelajaran tersebut. Oleh karena itu, mereka cenderung tidak memperdulikan bagaimana proses untuk mendapatkan konsep pengetahuan di kelas. 
Matematika adalah salah satu ilmu yang berperan penting dalam perkembangan dibidang sains dan teknologi. Menurut Permendikas No.22 Tahun 2006 salah satu tujuan dalam pembelajaran matematika adalah untuk memahami konsep matematika, menjelaskan keterkaitan antar konsep dan mengaplikasikan konsep atau algoritma secara luwes, akurat, efisien dan tepat alam pemecahan masalah. Nasution (2009:164) menyebutkan bahwa tanpa konsep, belajar akan sangat terhambat. Oleh karena itu, ketika mahasiswa belum memahami konsep pada materi sebelumnya maka ia akan kesulitan untuk memahami materi selanjutnya.

Pemahaman adalah suatu proses yang terdiri dari kemampuan untuk menerangkan dan menginterpretasikan sesuatu, mampu memberikan gambaran, contoh, dan penjelasan yang luas dan memadai serta mampu memberikan uraian dan penjelasan yang lebih kreatif, sedangkan konsep merupakan sesuatu yang tergambar dalam pikiran, suatu pemikiran, gagasan, atau suatu pengertian (Mawaddah, 2016:77). Pemahaman terhadap suatu konsep sangat penting dalam proses pembelajaran. Akan tetapi, mahasiswa cenderung memilih untuk menghafal rumus-rumus maupun cara penyelesaian yang dicontohkan oleh dosennya.

Pemahaman konsep perlu ditanamkan pada seorang mahasiswa sejak pertama kali ia menerima materi matematika pada proses pembelajaran dimulai dari tingkat dasar. Berdasarkan hasil penelitian Zevika, dkk (2012:49)menyimpulkan bahwa pemahaman konsep matematika merupakan hal yang dibutuhkan dalam mencapai hasil belajar yang baik. Pemahaman terhadap konsep-konsep matematika merupakan dasar untuk belajar matematika secara bermakna.Akan tetapi, mahasiswa ataupun dosen menjadikan hasil atau nilai akhir yang diperoleh menjadi patokan sejauhmana pemahaman konsep yang telah mahasiswa peroleh.

Berdasarkan paparan di atas, peneliti bertujuan untuk menganalisis keterkaitan antara pencapaian atau perolehan nilai akhir mahasiswa calon guru terhadap pemahaman konsep. Adapun indikator-indikator pemahaman konsep pada penelitian ini adalah menyajikan konsep dalam berbagai bentuk representasi matematis, menggunakan prosedur atau operasi tertentu, mengaplikasikan konsep atau algoritma pemecahan masalah (Jainuri dalam Relawati, 2016:165). Pemahaman konsep matematis ini memiliki kriteria penskoran untuk setiap butir soalnya, sebagai berikut. 
Tabel 1. Rubrik Penskoran Pemahaman Konsep.

\begin{tabular}{|c|c|c|c|}
\hline Nilai & $\begin{array}{l}\text { Menyajikan konsep kebentuk } \\
\text { representasi matematika }\end{array}$ & $\begin{array}{l}\text { Menggunakan prosedur atau } \\
\text { operasi tertentu }\end{array}$ & $\begin{array}{l}\text { Mengaplikasikan konsep atau } \\
\text { algoritma pemecahan masalah }\end{array}$ \\
\hline 0 & Tidak ada jawaban & Tidak ada jawaban & Tidak ada jawaban \\
\hline 1 & $\begin{array}{l}\text { Ada menyajikan konsep } \\
\text { kebentuk representasi tidak } \\
\text { benar dan tidak lengkap }\end{array}$ & $\begin{array}{l}\text { Ada menggunakan prosedur } \\
\text { atau operasi tertentu tidak } \\
\text { benar dan tidak lengkap }\end{array}$ & $\begin{array}{l}\text { Ada mengaplikasikan konsep } \\
\text { atau algortima pemecahan } \\
\text { masalah tidak benar dan tidak } \\
\text { lengkap }\end{array}$ \\
\hline 2 & $\begin{array}{l}\text { Ada menyajikan konsep } \\
\text { kebentuk representasi belum } \\
\text { lengkap dan hanya sebagian } \\
\text { dinyatakan benar }\end{array}$ & $\begin{array}{l}\text { Ada menggunakan prosedur } \\
\text { atau operasi tertentu belum } \\
\text { lengkap dan hanya sebagian } \\
\text { dinyatakan benar }\end{array}$ & $\begin{array}{l}\text { Ada mengaplikasikan konsep } \\
\text { atau algortima pemecahan } \\
\text { masalah belum lengkap dan } \\
\text { hanya sebagian dinyatakan } \\
\text { benar }\end{array}$ \\
\hline 3 & $\begin{array}{l}\text { Ada menyajikan konsep } \\
\text { kebentuk representasi lengkap } \\
\text { tetapi hanya sebagian dinyatakan } \\
\text { benar }\end{array}$ & $\begin{array}{l}\text { Ada menggunakan prosedur } \\
\text { atau operasi tertentu lengkap } \\
\text { tetapi hanya sebagian } \\
\text { dinyatakan benar }\end{array}$ & $\begin{array}{l}\text { Ada mengaplikasikan konsep } \\
\text { atau algortima pemecahan } \\
\text { masalah lengkap tetapi hanya } \\
\text { sebagian dinyatakan benar }\end{array}$ \\
\hline 4 & $\begin{array}{l}\text { Ada menyajikan konsep } \\
\text { kebentuk representasi benar dan } \\
\text { lengkap }\end{array}$ & $\begin{array}{l}\text { Ada menggunakan prosedur } \\
\text { atau operasi tertentu benar dan } \\
\text { lengkap }\end{array}$ & $\begin{array}{l}\text { Ada mengaplikasikan konsep } \\
\text { atau algortima pemecahan } \\
\text { masalah benar dan lengkap }\end{array}$ \\
\hline & Skor Maksimal 4 & Skor Maksimal 4 & Skor Maksimal 4 \\
\hline
\end{tabular}

Oleh karena itu peneliti tertarik untuk menganalisis "Keterkaitan Pencapaian Nilai Akhir dengan Pemahaman Konsep Matematis Mahasiswa Calon Guru”.

\section{Metode Penelitian}

Penelitian ini bertujuan untuk menganalisis keterkaitan pencapaian nilai akhir terhadap pemahaman konsep matematis mahasiswa calon guru pada mata kuliah program linier. Metode penelitian ini adalah deskriptif analisis dimana rancangan penelitian ini meliputi beberapa tahap yaitu (1) tahap persiapan, dimana peneliti menyusun dan menyempurnakan draf proposal dan instrumen bantu; (2) pemilihan subjek, proses pemilihan subjek pada penelitian ini adalah mahasiswa calon guru yang telah mempelajari dan mendapatkan nilai akhir pada mata kuliah program linier sehingga subjek penelitian ini merupakan mahasiswa calon guru semester 5 yang memiliki variasi pada nilai akhir mata kuliah program linier; (3) pengumpulan data diperoleh dengan cara memberikan masalah matematika sesuai dengan indikator-indikator pemahaman konsep pada penelitian ini; dan (4) analisis data dilakukan dengan beberapa langkah seperti reduksi data, penyajian data dan penarikan kesimpulan.

Sebelum menggunakan instrumen penelitian ini, peneliti terlebih dahulu memvalidasi instrumen tersebut kepada validator ahli. Validator pun menyatakan bahwa instrumen layak digunakan dengan memperbaiki kata-kata yang terdapat pada soal instrumen. 


\section{Hasil dan Pembahasan}

\section{Hasil}

\section{Pemilihan Subjek Penelitian}

Pemilihan subjek penelitian dimulai dengan pemberian soal instrumen pemahaman konsep pada kelas 5F mahasiswa Program Studi Pendidikan Matematika Universitas Muhammadiyah Prof. DR. HAMKA, dimana jumlah mahasiswa pada kelas tersebut sebanyak 14 mahasiswa/i. Berdasarkan hasil uji coba instrumen di kelas 5F, peneliti memilih 3 mahasiswa sebagai subjek untuk penelitian ini. Peneliti pun mempertimbangkan variasi nilai akhir mata kuliah program linier mahasiswa untuk memilihnya sebagai subjek. Berikut Tabel 2. Daftar subjek penelitian.

Tabel 2. Daftar Subjek Penelitian

\begin{tabular}{|c|c|c|c|}
\hline $\begin{array}{l}\text { Inisial } \\
\text { Nama } \\
\text { Subjek }\end{array}$ & Jenis Kelamin & $\begin{array}{c}\text { Nilai Akhir Mata Kuliah } \\
\text { Program Linier }\end{array}$ & $\begin{array}{l}\text { Nilai Instrumen Pemahaman } \\
\text { Konsep Matematis }\end{array}$ \\
\hline $\mathrm{AP}$ & Perempuan & $\mathrm{A}$ & 30 \\
\hline $\mathrm{MC}$ & Laki-Laki & B & 60 \\
\hline DL & Perempuan & $\mathrm{C}$ & 10 \\
\hline
\end{tabular}

\section{Paparan Analisis Keterkaitan Pencapaian Nilai Akhir Terhadap Pemahaman Konsep Matematis Pada Mata Kuliah Program Linier (Subjek AP)}

Peneliti mencoba menganalisis keterkaitan pencapaian nilai akhir yang diperoleh subjek AP pada mata kuliah program linier terhadap indikator-indikator pemahaman konsep matematis sebagai berikut.

Menyajikan konsep kebentuk representasi matematika

Subjek AP merincikan unsur atau data yang diketahui pada soal. Akan tetapi AP tidak memberikan pemisalan untuk membuat model matematika berdasarkan masalah yang diberikan. Ia langsung menuliskan unsur atau data yang diketahui pada soal menjadi sebuah pertidaksamaan $\mathrm{x}$ dan $\mathrm{y}$. AP hanya menuliskan tiga buah pertidaksamaan berdasarkan data-data tersebut, ia tidak memberikan fungsi kendala yang seharusnya ada untuk menyelesaikan atau menjawab soal yang diberikan. Oleh karena itu, sesuai dengan kriteria penskoran pemahaman konsep matematis pada penelitian ini, subjek AP mampu menyajikan konsep kebentuk representasi matematika soal yang diberikan walaupun penyelesaian yang diberikan tidak benar dan lengkap.

Menggunakan prosedur atau operasi tertentu 
Penyelesaian yang AP berikan pada soal instrumen selanjutnya menggunakan cara substittusi. Ketika ia sudah mendapatkan titik potong dari beberapa pertidaksamaan yang diketahui pada soal, AP mensubstitusikan nilai-nilai $\mathrm{x}$ dan $\mathrm{y}$ ke fungsi $\mathrm{z}$ atau fungsi kendala untuk mengetahui kesimpulan jawabannya. Adapun titik-titik tersebut yaitu $(20,20)$; $(24,48)$; $(28,-8)$; $(20,0)$; dan $(0,48)$. Berdasarkan titik-titik tersebut AP menarik kesimpulan bahwa nilai maksimum dari fungsi kendala terdapat pada titik $(24,48)$. Sesuai dengan kriteria penskoran pemahaman konsep matematis pada penelitian ini, subjek AP menggunakan prosedur atau operasi substitusi dalam menyelesaikan masalah yang diberikan walaupun belum lengkap dan hanya sebagian dinyatakan benar.

Mengaplikasikan konsep atau algortima pemecahan masalah

Subjek AP mencoba menelaah masalah pemecahan masalah yang diberikan oleh peneliti dengan menuliskan secara terinci unsur atau data yang diketahui dan ditanyakan pada soal. Adapun proses penyelesaian masalah yang dilakukan oleh AP, ia terlebih dahulu menentukan titik-titik potong dari pertidaksamaan yang diketahui pada soal. Selanjutnya AP mensubstitusikan titik-titik potong tersebut ke dalam fungsi kendala atau fungsi z untuk mencari nilai maksimum yang ditanyakan pada soal. Dan AP pun menyimpulkan bahwa nilai maksimum dari fungsi kendala $(Z=20 x+8 y)$ adalah 864 . Berdasarkan kriteria penskoran pemahaman konsep matematis pada penelitian ini, subjek AP menggunakan mengaplikasikan konsep atau algortima pemecahan masalah yang diberikan walaupun belum lengkap dan hanya sebagian dinyatakan benar.

\section{Paparan Analisis Keterkaitan Pencapaian Nilai Akhir Terhadap Pemahaman Konsep Matematis Pada Mata Kuliah Program Linier (Subjek MC)}

Peneliti mencoba menganalisis keterkaitan pencapaian nilai akhir yang diperoleh subjek MC pada mata kuliah program linier terhadap indikator-indikator pemahaman konsep matematis sebagai berikut.

\section{Menyajikan konsep kebentuk representasi matematika}

Subjek MC mencoba merincikan ketersediaan unsur atau data yang diketahui dan ditanyakan pada soal. Akan tetapi, MC hanya mampu untuk merepresentasikan masalah yang diberikan dengan memisalkan data yang diketahui dengan simbol x dan y sedangkan untuk data yang ditanyakan MC tidak menuliskannya pada lembar jawabannya. Oleh karena itu, sesuai dengan kriteria penskoran pemahaman konsep matematis pada penelitian ini, subjek MC mampu menyajikan konsep kebentuk representasi matematika soal yang diberikan walaupun penyelesaian yang diberikan tidak benar dan lengkap. 


\section{Menggunakan prosedur atau operasi tertentu}

Proses penyelesaian yang dilakukan oleh MC pada masalah yang diberikan tanpa menggunakan prosedur atau operasi tertentu. Ia menyatakan menggunakan cara coba-coba untuk menghasilkan kesimpulan jawaban dari soal tersebut. Selain itu, MC pun melakukan perhitungan yang kurang tepat pada proses pengerjaannya sehingga kesimpulan jawaban yang dihasilkan pun salah. Sesuai dengan kriteria penskoran pemahaman konsep matematis pada penelitian ini, subjek MCmencoba menggunakan prosedur atau operasi perhitungan dengan cara coba-coba dalam menyelesaikan masalah yang diberikan walaupunpenyelesaian tersebut tidak benar dan lengkap.

Mengaplikasikan konsep atau algortima pemecahan masalah

Serupa dengan penyelesaian soal sebelumnya, subjek MChanya menggunaka cara cobacoba untuk mengartikan soal pemecahan masalah yang diberikan. Ia pun keliru dalam melakukan operasi hitung yang dituliskan pada lembar jawabannya. MC mencoba untuk menggambar grafik dari pertidaksamaan yang diketahui pada soal untuk menentukan titiktitik potong. Akan tetapi, MC keliru dalam menuangkan pertidaksamaan tersebut ke dalam bentuk grafik sehingga titik-titik potong yang didapatnya pun keliru. Berdasarkan kriteria penskoran pemahaman konsep matematis pada penelitian ini, subjek MC menggunakan mengaplikasikan konsep atau algortima pemecahan masalah yang diberikan walaupunoperasi perhitungan yang ia lakukan tidak benar dan lengkap.

\section{Paparan Analisis Keterkaitan Pencapaian Nilai Akhir Terhadap Pemahaman Konsep Matematis Pada Mata Kuliah Program Linier (Subjek DL)}

Peneliti mencoba menganalisis keterkaitan pencapaian nilai akhir yang diperoleh subjek DL pada mata kuliah program linier terhadap indikator-indikator pemahaman konsep matematis sebagai berikut.

\section{Menyajikan konsep kebentuk representasi matematika}

Dalam menyajikan konsep kebentuk representasi matematika, subjek DL menuliskan data yang diketahui pada soal dengan membuatkan tabel dan memisalkan microbus sebagai $\mathrm{x}$ serta bus sebagai y. Ia pun menuliskan data yang ditanyakan pada soal. Dalam menyelesaikan masalah yang diberikan, DL membuat dua buah pertidaksamaan dimana salah satu pertidaksamaan tersebut keliru yaitu DL kurang memberikan " 0 " pada pertidaksamaan yang ia sajikan. Selain itu, DL pun keliru dalam menentukan model matematika dari fungsi kendala atau fungsi $\mathrm{Z}$ pada soal. Oleh karena itu, sesuai dengan kriteria penskoran pemahaman konsep matematis pada penelitian ini, subjek DL mampu 
menyajikan konsep kebentuk representasi matematika soal yang diberikan walaupun penyelesaian yang diberikan tidak benar dan lengkap.

Menggunakan prosedur atau operasi tertentu

Prosedur penyelesaian yang dilakukan oleh DL pada masalah yang diberikan dengan menentukan titik-titik potong untuk pertidaksamaan yang diketahui. Selanjutnya ia mencoba untuk menggambarkan sebuah grafik berdasarkan titik-titik potong tersebut untuk menentukan himpunan penyelesaian soal yang diberikan. Akan tetapi, DL melakukan kekeliruan dalam menginterpretasikan pertidaksamaan ke dalam grafik sehingga himpunan penyelesaian yang dihasilkan pun keliru. DL tetap memberikan kesimpulan jawaban yaitu nilai maksimum untuk soal yang diberikan sebesar 480 pada titik $(24,0)$. Kekeliruan yang dituangkan oleh DL dalam sebuah grafik pun menghasilkan kesimpulan jawaban yang salah. Sesuai dengan kriteria penskoran pemahaman konsep matematis pada penelitian ini, subjek DLmencoba menggunakan prosedur atau operasi perhitungan dengan caramencari titik potong dan menggambarkan grafik dalam menyelesaikan masalah yang diberikan walaupunpenyelesaian tersebut tidak benar dan lengkap.

Mengaplikasikan konsep atau algortima pemecahan masalah

Algoritma pemecahan masalah yang diterapkan oleh DL serupa dengan penyelesaian soal sebelumnya, subjek DLmencoba mencari titik-titik potong dari pertidaksamaan yang diketahui pada soal untuk dituangkannya pada sebuah grafik. Tetapi, DL kesulitan dalam menggambarkan grafik yang tepat untuk pertidaksamaan tersebut sehingga ia pun keliru dalam menentukan himpunan penyelesaiannya. Berdasarkan kriteria penskoran pemahaman konsep matematis pada penelitian ini, subjek DL menggunakan mengaplikasikan konsep atau algortima pemecahan masalah yang diberikan walaupunoperasi perhitungan yang ia lakukan tidak benar dan lengkap.

\section{Pembahasan}

Pemaparan hasil analisis ketiga subjek berdasarkan soal instrumen pemahaman konsep matematis mengindikasikan bahwa penilaian akhir yang diperoleh subjek tidak berbanding lurus dengan pemahaman konsep yang ia miliki. Subjek MC yang mendapatkan nilai akhir mata kuliah program linier B memiliki nilai instrumen pemahaman konsep yang lebih tinggi dibandingkan dengan subjek AP. Subjek AP mampu menyelesaikan semua soal yang diberikan tetapi ia tidak mampu untuk menghasilkan kesimpulan jawaban yang benar. 
Sedangkan perolehan nilai akhir mata kuliah program linier oleh subjek DL yaitu C berbanding lurus dengan kurangnya pemahaman konsep yang dimilikinya. Hal ini terlihat dari nilai pemahaman konsep yang ia dapatkan yaitu 10. Selain itu kurangnya pemahaman konsep matematis yang dimiliki oleh DL tertuang pada hasil kerja yang ia tuliskan pada lembar jawaban instrumen pemahaman konsep yang diberikan.

\section{Simpulan dan Saran}

Berdasarkan pemaparan yang telah peneliti ungkapkan di atas, simpulan yang mampu peneliti berikan adalah pencapaian yang tinggi pada nilai akhir pada mata kuliah program linier tidak selalu berbanding lurus dengan pemahaman konsep yang dimiliki oleh mahasiswa calon guru matematika. Hal tersebut terlihat dari hasil analisis yang telah dituangkan di atas. Selain itu, setelah melakukan penelitian ini, peneliti pun memberikan saran agar (1) dosen lebih berusaha dalam mengembangkan pemahaman konsep matematis kepada mahasiswa calon guru; (2) dosen lebih kreatif dalam mengaplikasikan metode atau model atau media pembelajaran untuk mengembangkan pemahaman konsep matematis sesuai dengan indikator-indikator di dalamnya; dan (3) dosen memberikan motivasi pada mahasiswa calon guru agar tidak hanya mengejar pencapaian nilai akhir tetapi juga menekannya pada proses pemahaman konsep matematis yang diberikan oleh dosen.

\section{Referensi}

Mawaddah, Siti dan Ratih Maryanti. 2016. Kemampuan Pemahaman Konsep Matematis Siswa SMP dalam Pembelajaran Menggunakan Model Penemuan Terbimbing (Discovery Learning). EDU-MAT Jurnal Pendidikan Matematika, Volume 4, Nomor 1, April 2016 hal 76-85.

Nasution, S. 2009. Berbagai Pendekatan Dalam Proses Belajar \& Mengajar. Jakarta: Bumi Aksara.

Relawati dan Nurasni. 2016. Perbandingan Kemampuan Pemahaman Masalah Matematis Melalui Model Pembelajaran CORE dan Pembelajaran Langsung Pada Siswa SMP. Mendidik: Jurnal Kajian Pendidikan dan Pengajaran, Volume 2, No.2 Oktober 2016 hal 161-169. P-ISSN:2443-1435, E-ISSN: 2528-4290.

Zevika, Mona, dkk. 2012. Meningkatkan Kemampuan Pemahaman Konsep Siswa Kelas VII SMP Negeri 2 Padang Panjang Melalui Pembelajaran Kooperatif Tipe Think Pair Share I Disertai Peta Pikiran. Jurnal Pendidikan Matematia 1(1): 45-50 